\title{
Erratum to: Ferulic acid chronic treatment exerts antidepressant-like effect: role of antioxidant defense system
}

\author{
Juliana Lenzi ${ }^{1}$ - Andre Felipe Rodrigues ${ }^{2}$ - Adriana de Sousa Rós ${ }^{1}$. \\ Amanda Blanski de Castro ${ }^{1}$ - Daniela Delwing de Lima ${ }^{3}$. \\ Débora Delwing Dal Magro ${ }^{2}$ Ana Lúcia Bertarello Zeni ${ }^{1}$
}

Published online: 26 October 2015

(C) Springer Science+Business Media New York 2015

Erratum to: Metab Brain Dis (2015)

DOI 10.1007/s11011-015-9725-6

The original version of this article unfortunately contained a mistake in one of the authors' name. The correct author's name is "Amanda Blanski de Castro". The authors regret this error.

The online version of the original article can be found at http://dx.doi.org/ 10.1007/s11011-015-9725-6.

\footnotetext{
Ana Lúcia Bertarello Zeni

anazeni@furb.br; zeni.ana@gmail.com

1 Laboratório de Análise de Substâncias Bioativas, Departamento de Ciências Naturais, Universidade Regional de Blumenau, Campus I, Blumenau 89012-900, Santa Catarina, Brazil

2 Laboratório de Fisiologia, Departamento de Ciências Naturais, Universidade Regional de Blumenau, Blumenau 89012900, Santa Catarina, Brazil

3 Departamento de Medicina, Universidade da Região de Joinville, Joinville 89219-710, Santa Catarina, Brazil
} 